\title{
Left Posterior Fascicular Block by ECG
}

\section{Finding}

National Cancer Institute

\section{Source}

National Cancer Institute. Left Posterior Fascicular Block by ECG Finding. NCI Thesaurus.

Code C62268.

An electrocardiographic finding of an S1Q3 pattern and QRS axis greater than or equal to 120 degrees. It is usually seen in association with other abnormalities (e.g. RBBB or $\mathrm{RVH}) .(\mathrm{CDISC})$ 